International Journal of Advanced Studies in Humanities and Social Science (IJASHSS)

Available online at http://www.ijashss.com

Volume 8, Issue 2 (2019) pp. 158-167

Original Article

\title{
The Role of Mediator Vision in the Relationship between Leadership Style and Organizational Learning
}

\section{Somayeh Naseramini Jelodarloo ${ }^{1}$, Eslam Nazari2 ${ }^{*}$, Zaher hatami ${ }^{3}$, Karamat Nouri ${ }^{4}$, Saber Nazari ${ }^{5}$}

\author{
1Department of Business Management, Bilesavar Branch, Islamic Azad University, Bilesavar, \\ Iran \\ 2Department of Business Management, Bilesavar Branch, Islamic Azad University, Bilesavar, \\ Iran \\ ${ }^{3}$ Department of Industrial Management, Bilesavar Branch, Islamic Azad University, \\ Bilesavar, Iran \\ ${ }^{4}$ Department of Executive Management, Bilesavar Branch, Islamic Azad University, \\ Bilesavar, Iran \\ ${ }^{5}$ M.Sc. Student of English Language Teaching, University of Ahar, Ahar, Iran \\ *Corresponding Author E-mail: Nazari1362mba@yahoo.com
}

Received: 24 October 2018, Revised: 05 December 2018, Accepted: 20 December 2018

\begin{abstract}
One result of organizational learning is to gain competitive advantage. In the current status that all organizations facing the intense competition and ongoing changes in market requirements, having the sustainable competitive advantage is critical and applying the appropriate leadership style of management is one of tools to gain competitive advantage for today's organizations manager. The importance of the purpose of the present study is to investigate the relationship between leadership style and organizational learning; in addition, its role in mediating the prospects are assessed. Research population includes managers, principals and teachers of schools in the Jafarabad. Data were collected from the questionnaire used in this study. After the pre-test questionnaire and ensure high reliability (Cronbach's alpha 0.97), 160 questionnaires were distributed and collected from Jafarabad school on October 2013 and SPSS software was used in order to analyze the data. Pearson correlation coefficient and ANOVA analysis were used to test the hypotheses.The results of this research indicate that leadership style has a direct effect and indirect effect on organizational learning and between leadership style with vision and with organizational learning and also there is a significant positive relationship between leadership style and organizational learning.
\end{abstract}

Keywords: Vision, Leadership Style, Organizational Learning, Changer. 


\section{Introduction}

Today, most organizations need to change fast to maintain their competitive position. Fast changes need organizations with leaders and employees who are adaptable and work effectively, improve systems and processes continually and are responsible for customer requirements (Mortazavi et al., 2005). Human resources as the most important strategic resource in any organization play an important role in achieving organizational goals and are the driving force (Gholizdeh et al., 2010). Organizational learning is a platform enabling human resources in the organization. Ability to learn faster than competitors is a sustainable competitive advantage for organizations (Allama and Moghaddam, 2010). Therefore, organizations should constantly follow the environmental changes and keep up with changes of organizational learning (Mirkamaly et al., 2011). There is no doubt, learning with attendance and active participation of the individual and organization, technology and knowledge to provide appropriate contexts of learning such as educational facilities and organizational structures are done (Niaz Azeri et al., 2010). Higher Education Quality Council of England (2003) concluded that the success of managers in higher education is influenced by their efforts to institutionalize organizational learning culture in the organization and organizational learning is suitable way for managers and argues that this approach of the learning process as a process of selfconscious becomes a non-conscious process and creates an inherent authority in the personnel of these institutions (Hejazi and Rezaei, 2007). The results show that organizational learning has effects on competitive and collaborative benefits of tangible and intangible nonfinancial and financial performance and innovation (Mirkamaly et al., 2011). School success mainly depends on school leaders (Hanna et al., 2010). If the directors fail in their roles and responsibilities and their desired objectives are not exceeded, its prejudicial results directly to deal with group or organization that they work with it (Gholizdeh et al., 2010). School leaders is responsible for the way teachers teach and how schools learning student. The impact of school leadership is mostly indirect. Leaders by the vision to guide the learning process have an impact on student's learning. Vision as a considered leadership principle aims to link teacher's goal will lead them to achieve ambitious goals (Hanna et al., 2010). Vera and Krasvn (2004) after analyzing their research results suggest that transformational leadership, through vision, facilitates organizational learning process and dynamic environment as an important mediator acts in the relationship between perception of leadership and organizational learning (Mirkamaly et al., 1390). Increased competition among schools has caused them to be looking for ways to gain competitive advantage. The use of appropriate leadership as a style is one tool to gain competitive advantage for present school administrative. Given the importance of this paper seeks to examine the relationship between leadership style and learning in the Jafarabad schools using school vision as the mediator variable.

\section{The Importance and Necessity of Research}

Complex and series changes in the external and internal environments, organizations managers have prompted to have paid much attention to the use of new theory of leadership. Today, managers are not dealing with people who have no knowledge, but they are people with head 
knowledge and different needs than the past, so managers cannot raise people using ancient techniques in order to achieve organizational goals. So, the time has come for the leaders to use the new methods of management in leadership (Beik Zadeh and Phalsaphi, 2009). Due to the existing changing environment that organizations with rapidly changing and complex circumstances of facing with that, the leader has an essential role to adapt the organization quickly to variable environmental conditions and keep the stability of organization (Ghorbanian et al., 2010). Educational institutes success primarily depends to the leaders and teachers tendency to adhere to the schools vision, creating a sense of purpose, link them together and encourage them to engage in continuous learning. Leadership, vision and organization learning as a key factor in improving schools will be considered (Kurland et al., 2010). Vera and Krasvn (2004), after analyzing the results of their research, suggest that transformational leadership, through the creation of vision, facilitates organizational learning and environments dynamic works as an important mediator in perceiving the relationship between leadership and organizational learning (Papalexandris and Galanaki, 2009). According to given material and the important role of leading in organizational learning, it is felt necessary that the relationship between leadership style and learning in schools Jafarabad using school vision as the mediator variable are investigated.

\section{Theoretical Framework}

\section{Leadership Style}

The leader is a person who sees a vision and does necessary actions to achieve the vision and following others as the company and doing the changes (Laub,
2004) as well as have the ability to use a minimum of coercion, influence and motivate others to make a commitment (Kurland et al., 2010). Successful organizations have an important characteristic by which they are distinguished from unsuccessful organizations; this leader's characteristic is dynamic and effective (Ghorbanian et al. 2010). Leadership plays a crucial role in the dynamics of the organization and is the most important issue in the field of organizational behavior and human relationships (Gholizdeh et al., 1389). Leadership style is constant and permanent behavioral patterns are used by people working with others, it will be understood by others (Ghorbanian et al., 2010). Many experts believe that their styles are influenced by the attitude of its own role and his staff (Gholizdeh et al., 2010). Style of transformational leadership and lack of mediator is most recent classification of non-interventionist style (Ghorbanian et al., 2010).

\section{Organizational Vision}

Vision will create a bridge between today and tomorrow, and to encourage and motivate employees to work towards the future, gives meaning to people's work and provides a standard of excellence in the organization and nothing more than an image of the future and a power of inspiration, motivation and commitment of the people. Leaders who create new visions, insights and inspiration led to the formulation and development of change and innovation and motivate followers and create harmony in their commitment and responsibility, organizational elements which are used in such a way as to ensure the survival of the organization, and provide their growth necessity. These leaders have the ability to operate effectively in a complex and risky 
conditions, and create the sense in self and their subordinates to express appropriately respond to the challenges and opportunities (Mirkamaly et al., 2011). Having a vision and goals for everyone in the organization create shared challenges, incentives and common goals. Vision not only defines the organization goals, but the means to achieve it (Kurland et al., 2010). Shared vision raises attention to common goals. (SM macro Associates, 1391, p 50) there is no prospect of any creative tension (Seyed Kolun et al., 2012).

\section{Organizational Learning}

Organizational learning is a dynamic process that enables organizations to be quickly adapted. This process includes producing new knowledge, skills and attitudes.

Organizational learning is the main way to improve the knowledge working and efficiency of the organization; so a successful organization must be in active learning (Khan Alizadeh et al., 2010). To success schools, to understand the learning value as a continuous process by teachers is essential. Consequently, organizational learning, both for the organization and for the quality of work life is important. Schools that are taking steps in organizational learning can enable employees at all levels use their organizational learning in response to social needs and environmental demands (Kurland et al., 2010). Learning organization is an organization that continuously learns from its experiences and will create its future and constantly uses the learning to adapt to the changing environment (Voulalas, Sharpe, 2005). Evidence suggests that those organizational activities that are done to organizational learning improve effectiveness (Kurland et al., 2010). Kurland and Hertz-Lazarowitz learning mechanisms (2006) includes: Employee participation, evaluation, expertise development in information and schools (Mirkamaly et al., 2011).

\section{Review of Literature}

Regression analysis of mediator variables in Kurland et al. (2010) research entitled "Study the relationship between leadership style and organizational learning from mediator vision" shows schools vision predicting a significant relationship with organizational learning. On the one hand, it works as a mediator variable between leadership style and organizational learning. In addition to the principles of transformational leadership style, predicting school vision and organizational learning, it means schools vision by managers and staff who are in the process of organizational learning. Research carried out by Mirkamaly et al. (2011) as "The study of the relationship between transformational leadership and organizational learning" shows that there is a significant and positive relationship between components of transformational leadership and organizational learning. Finally, idealized influence (behavior) as one of the dimensions of transformational leadership is the most important predictor of organizational learning. Yidrma et al. (2008) research entitled "Study of the relationships between perceived leadership style of teachers, student learning styles and academic achievement of high school students began with the multivariate analysis which showed that teacher's leadership style is the main factor affecting on academic achievement. Amitay et al. (2005) in an article entitled "Impact of leadership style on organizational learning in hospitals" studied leadership style and organizational learning in 44 clinics and reached the conclusion that 
transformational leadership has greater impact on activities of organizational learning.

\section{Research Conceptual Model}

Research by Hana Kurland et al. (2010) as "The study of the relationship between leadership style and organizational learning with mediated vision" was to show that vision variable as mediator variable between leadership style and organizational learning acts on the study whose conceptual model is as follows:

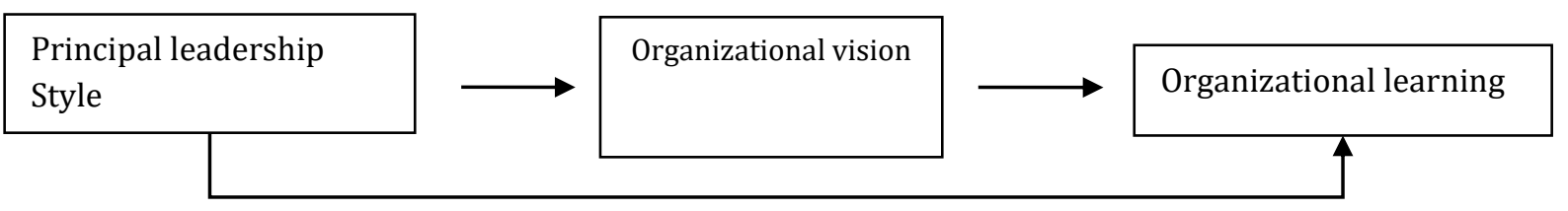

Figure 1. Conceptual Model Derived From Kurland Et Al Research (2010)

\section{Research Hypothesis}

1. There is a significant relationship between leadership style and organizational learning. 2. There is a significant relationship between leadership style and organizational vision.

3. Vision at the relationship between leadership style and organizational learning acts as a mediator.

\section{Research Aim}

Given that organizational learning is the factor of enabling human resources in organization and today, organizations are more successful and learn sooner, faster and better than the competitors but learn and learning through the work process, this paper shows the relationship between the leadership styles, the vision of organizational learning in the schools Jafarabad, and the study of whether there is a relationship between leadership styles and vision and leadership styles and organizational learning, and if so what.

\section{Research Methodology}

The study from purpose view is applied, and from method view is analytical and correlational. The study recruited by school managers in Jafarabad on the 20122013 academic year, including 28 cases against each principal director of school 3 to 5 people at random (based on the book of performance instruction MLQ tool for every director, 3 up to 5 followers or codirector have to response to the questionnaire with respect to coworker) of direct assistance to them including principals and teachers in schools where 306 men participated in this study had a total of 334 people have set up and 160 questionnaires were distributed and the same amount was also analyzed .

The questionnaire consists of 52 items and includes managers' leadership style, schools vision and organizational learning and Likert scale including five options of always, often, sometimes, rarely, never was used. Leadership style was measured by Salzmann's Multifactor leadership Questionnaire and Bass and Alive MLQ form $5 \mathrm{x}$ the third edition. Base was school vision questionnaire in Hanna Kurland et al. research (2010) and organizational learning 
questionnaire in Khakzar and Aqdasi research (1387). Firstly, the questions of research was gathered from interviews with experts as well as content completeness, as well understandability of the content validity of the questions to be determined witch is the same as content reliability.

Cronbach's alpha method has been used for calculating the reliability of this questionnaire and 0.97 is obtained, and on this basis, we can say that the questionnaire has acceptable reliability using the Kolmogorov - Smirnov normal distribution. Based on the organizational learning variables (sum of all aspects of organizational learning) and different leadership styles (average of all questions) and vision variables (average of all questions) have followed the normal distribution.

\section{Research Results}

\section{Hypothesis Test}

Method of data analysis and hypothesis testing is thus the primary data collected using a questionnaire and then presented testing the hypotheses here.

In this study, we investigate the effect of independent variables on the dependent variable of Pearson correlation and in order to examine the mediating variables organizational vision from path analysis.

Hypothesis 1: There is a significant relationship between leadership style and organizational learning.

According to Table 1, it can be seen that sig $=/ 000</ 01$. Therefore, the hypothesis was confirmed with $99 \%$ validity, and this relationship is significant. Based on this table, we can say correlation between leadership style and organizational learning is $96.5 \%$, which is an indication of a direct relationship between two variables. On the other hand, the coefficient of determination between leadership style and organizational learning is $9312 \%$, which indicates that the independent variable is the rate of $93.12 \%$ could predict the dependent variable.

Table 1. The Results of Pearson Correlation Coefficients for the Variables of Leadership Style

\begin{tabular}{cccc}
\hline & & $\begin{array}{c}\text { Leadershi } \\
\text { p style }\end{array}$ & Organizational Learning \\
\hline Leadership style & Pearson Correlation & 1 & $0.965^{* *}$ \\
& Significant & & 0.000 \\
Organizational Learning & Number & 160 & 160 \\
& Pearson Correlation & $0.965^{* *}$ & 1 \\
& Significant & 0.000 & 160 \\
& Number & 160 & 160 \\
\hline
\end{tabular}

Hypothesis 2: There is a significant relationship between organizational vision and organizational learning.

According to Table 1, it can be seen that sig $=/ 000</ 01$. Therefore, the hypothesis was confirmed with 99\% validity, and this relationship is significant. Based on this table, we can say correlation between organizational vision and organizational learning is $96.1 \%$, which is an indication of a direct relationship between two variables. On the other hand, the coefficient of determination between organizational vision and organizational learning is $9335 \%$, which indicates that the independent variable is the rate of $93.35 \%$ could predict the dependent variable. 
Table 2. The results of Pearson Correlation Coefficients for the Variables of Organizational Vision

\begin{tabular}{|c|c|c|c|}
\hline & & $\begin{array}{c}\text { Organizational } \\
\text { Vision }\end{array}$ & $\begin{array}{l}\text { Organizational } \\
\text { Learning }\end{array}$ \\
\hline \multirow{3}{*}{ Organizational Vision } & Pearson Correlation & 1 & $0.961^{* *}$ \\
\hline & Significant & & 0.000 \\
\hline & Number & 160 & 160 \\
\hline \multirow[t]{3}{*}{ Organizational Learning } & Pearson Correlation & $0.961^{* *}$ & 1 \\
\hline & Significant & 0.000 & \\
\hline & Number & 160 & 160 \\
\hline
\end{tabular}

Hypothesis 3: organizational vision on the relationship between leadership style and organizational learning acts as a mediator.

In order to realize that the claim is true or false, path analysis method is employed. In this method, regression analysis is used and with respect to general models in which the independent variables effect on the dependent variable directly or indirectly, the size of the direct and indirect effects is calculated, and finally, if the vision has direct effects and indirect effects, the conclusion can be drawn to the result that the present variable has mediating role in the model. The effects of vision and leadership will be measured using the regression method. In the path analysis model leadership style was hypothesized showing direct and indirect effects on organizational learning. To estimate the size of these paths, a series of regression analyses was carried out as follows.

Regression analysis when variable of organizational learning is considered dependent and variables of leadership style and vision are independent is shown in Table 3.

According to Table (3), coefficients of path between organizational learning and two variables is obtained. In accordance with the table, both leadership style and vision variables are inserted in the equation and predictor variables are significant. Standardized beta values are standardized in coefficients column and standardized regression coefficients between two variables and leaning variable show (i.e., the beta related to leadership style is 0.537 ; the beta related to vision is 0.449 ).

Table 3. The Results of Organizational Learning Variable Regression Analysis, Leadership Style and Vision Variable

\begin{tabular}{|c|c|c|c|c|c|c|c|}
\hline & $\begin{array}{c}\text { Non- } \\
\text { Standardized } \\
\text { coefficients }\end{array}$ & $\begin{array}{c}\text { Standardized } \\
\text { coefficients }\end{array}$ & & & & & $\begin{array}{c}\text { Validity } \\
\text { interval } \\
95 / 0 \mathrm{~B}\end{array}$ \\
\hline Model & B & $\begin{array}{c}\text { Standard } \\
\text { Deviation } \\
\text { Error }\end{array}$ & Beta & $\mathbf{T}$ & Significant & Lower & Higher \\
\hline Constant & $1 / 838$ & $0 / 054$ & & $33 / 909$ & $0 / 000$ & $1 / 731$ & $1 / 945$ \\
\hline $\begin{array}{l}\text { leadership } \\
\text { style }\end{array}$ & $0 / 692$ & $0 / 015$ & $0 / 965$ & $46 / 124$ & $0 / 000$ & $0 / 663$ & $0 / 722$ \\
\hline Constant & $1 / 151$ & $0 / 103$ & & $11 / 147$ & $0 / 000$ & $0 / 947$ & $1 / 355$ \\
\hline $\begin{array}{l}\text { leadership } \\
\text { style }\end{array}$ & $0 / 385$ & $0 / 043$ & $0 / 537$ & $8 / 925$ & $0 / 000$ & $0 / 300$ & $0 / 470$ \\
\hline $\begin{array}{l}\text { Organization } \\
\text { vision }\end{array}$ & $0 / 447$ & $0 / 060$ & $0 / 449$ & $7 / 464$ & $0 / 000$ & $0 / 329$ & $0 / 564$ \\
\hline
\end{tabular}


According to Table (4), coefficients of path between vision and leadership style is obtained. In accordance with the table, leadership style is significant predictor variables for vision variables and standardized beta values is 0.954 ).

Table 4. The Results of Regression Analysis of Leadership Style and Vision Variable

\begin{tabular}{|c|c|c|c|c|c|c|c|c|}
\hline \multirow{2}{*}{\multicolumn{2}{|c|}{ Model }} & \multirow{2}{*}{\multicolumn{3}{|c|}{ 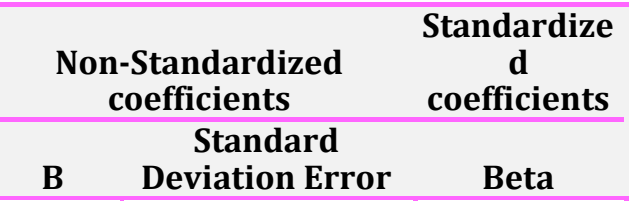 }} & \multirow[b]{2}{*}{$\mathbf{T}$} & \multirow[b]{2}{*}{ Significant } & \multicolumn{2}{|c|}{$\begin{array}{c}\text { Validity interval } \\
95 / 0 \mathrm{~B}\end{array}$} \\
\hline & & & & & & & Lower & Higher \\
\hline \multirow[t]{2}{*}{1} & Constant & 1.536 & 0.062 & & 24.757 & 0.000 & 1.413 & 1.658 \\
\hline & $\begin{array}{l}\text { leadership } \\
\text { style }\end{array}$ & 0.687 & 0.017 & 0.954 & 39.336 & 0.000 & 0.653 & 0.721 \\
\hline
\end{tabular}

\section{Results from two Regression Analysis}

In Figure (2), the written amounts on the arrows are the betas because they are positive, show positive relationships between two variables. To calculate the indirect effect of each independent variable on the dependent variable, indirect effects of independent variables on the dependent coefficients of all the paths in multiply, and then the outcome of this impact will be summed.

$0 / 954 * 0 / 449=0 / 428$

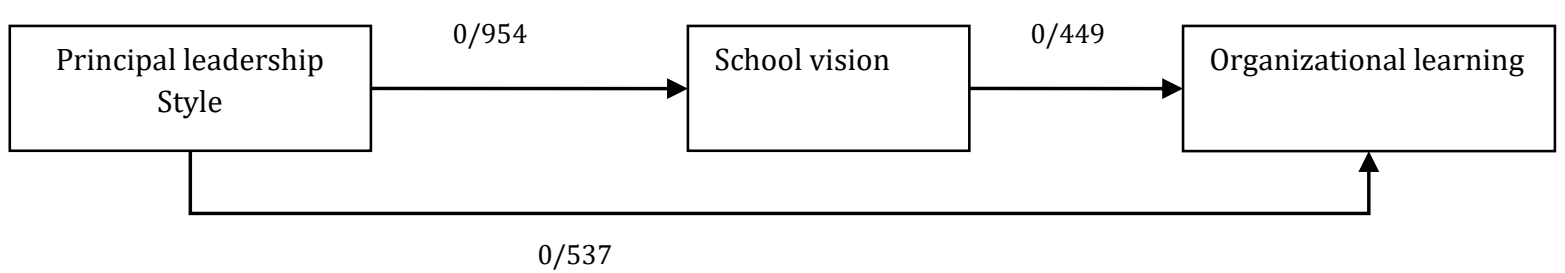

Figure 2. Path Model With Regression Coefficients

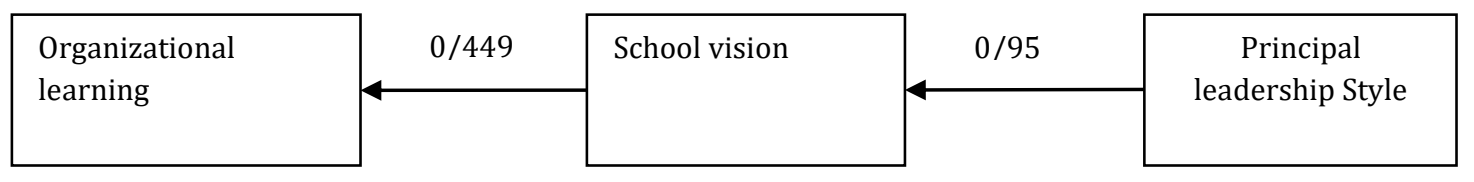

Figure 3. Path Model and the Indirect Effect

Table 5. Summary of Direct and Indirect Effects of Leadership Style and Organization and Organizational Learning Vision

\begin{tabular}{|c|c|c|c|c|}
\hline & & $\begin{array}{l}\text { direct } \\
\text { effects }\end{array}$ & $\begin{array}{c}\text { indirect } \\
\text { effects }\end{array}$ & Sum effect \\
\hline \multirow{3}{*}{$\begin{array}{l}\text { Principal leadership Style } \\
\text { Principal leadership Style } \\
\text { School vision }\end{array}$} & $\longrightarrow$ & 0.954 & & 0.954 \\
\hline & $\longrightarrow$ Organizational learning & 0.537 & 0.428 & 0.965 \\
\hline & $\longrightarrow \quad$ Principal leadership & 0.449 & & 0.446 \\
\hline
\end{tabular}

\section{Conclusion and Suggestions}

Development and spread of science and technology, more complex social factors, cultural, political, economic, technology, and the introduction of new ideas, 
environmental uncertainty, and constantly changing world made the importance of organizational learningmore evident. Therefore, great importance has been attached to the role of leadership in organizational learning. Successful and effective manager's results in organization learning, improved staff cohesion ultimately resulting in the development of professional associations in their organization (Mirkamaly et al., 2011). Managers by creating new vision and applying the suitable leadership style guaranteeing the survival and provide growth of organizations. Leadership style according to the vision of the organization is important in creating a learning organization. Investigate the relationship between leadership style and organizational learning and vision is the main objective of this research. The study confirmed a significant relationship between leadership style and organizational learning that the results are in agreement with those of Hana Kurland et al. (2010), Mirkamaly et al. (1390), Amity et al. (2005) and Yildrma et al. (2008). Similarly, a significant relationship between leadership style and vision and organizational learning and vision was confirmed that are in agreement with the results of Hanna Kurvand et al. (2010). Respect to our results could be due to the following suggestions for improving the organization's managers:

1. Provide opportunities and conditions for group and organizational learning

2. Follower Freedom in order to uses different strategies of learning

3. Giving freedom to the follower of job rotation

4. Encourage employees to work harder

5. Widespread support from the school's vision

6. Clarity of organizational values
7. Widespread supports from the union statement

8. Forming problem solving groups

9. Enhance learning at all levels and create opportunities for people to acquire knowledge from different sources

10. The development of appropriate information and communication among schools

11. Empowering employees at all levels of learning

\section{References}

Allamah S.M. \& Moghadami M. (2010). Examine the relationship between organizational learning and organizational performance: A case study of Iran power propulsion. Journal of Management components, Tenth year Serial number 1 (38): 75-99.

Amitay, M., Popper, M. and Lipshitz, R. (2005), "The effects of leadership style on organizational learning in community clinics", The Learning Organization, Vol. 12 No. 1, pp. 57-70

Azymh Ghorbanian, A., Hdadpour A., Maleki M.R. (2010).The relationship between leadership style (transformational, harmless, exchanges, brokers) Emergency medical technicians, managers and job satisfaction of city in Isfahan city: 1-17.

Beik Zadeh, J., Phalsefi A. (2009). Transformative Organizational Leadership, Worked and Society, No.8 1-11.

Hjay Joseph Vaisi H. (2007). Explain the components of organizational learning in higher education institutions farm (case study of Tehran University College of Agriculture and Natural Resources). Journal of Research and Planning in Higher Education, (46):65-45. 
Gholizdeh M.R., Asghrfany A., Ahmadvand A.M. (2010). The effect of leadership on job satisfaction of police personnel risks (Study of Budget and Planning staff and police budgets. Cop Journal of Human Development) No29 28-45.

Hanna K., Peretz H., Rachel H.L. (2010)," Leadership style and organizational learning: the mediate effect of school vision, Journal of Educational Administration Vol. 48 No. 1, 2010 pp. 730.

Kurland, H. and Hertz-Lazarowitz, R. (2006), "Organizational learning as a lever for realizing an educational vision", Dapim, Vol. 41, pp. 230-71.

Laub, J. (2004). Ditining Servant Leadership: A Rccommended Typology for Servant Leaddership Studies, Servant Leadership Roundtable, August, pp:1-12.

Mortazavi S., Nazmi Sh., Mahmoodi S.F. (2005). Study relationship between intelligence and leadership style (transformational part - exchange).

$\begin{array}{lcr}\text { Quarterly } & \text { Humanities, } & \text { Special } \\ \text { Management, } & \text { fall: } & 167-190\end{array}$

Mirkmaly Syed M., Narenji Sani F., Alami F. (2011). Investigate the evolutionary relationship between leadership and organizational learning. This letter change management. Third year No. 6: 27-1
Papalexandris N., Galanaki E. (2009)," Leadership's impact on employee engagement", Leadership \& Organization Development Journal Vol. 30 No. 4, pp. 365-385

Voulalas, Z.D. and Sharpe, F.G. (2005), "Creating schools as learning communities: obstacles and processes", Journal of Educational Administration, Vol. 43 No. 2, pp. 187-208.

Yildirima, o, Acarb, A.C., Bullc, S. And Servincb, L. (2008), Relationships between teachers, perceived leadership style, student's learninig style, and academic achievement: a study on high school students. Educationa psychology, vol. 28, No.1, January 2008, 73-81

How to cite this article: Somayeh Naseramini Jelodarloo, Eslam Nazari, Zaher hatami,Karamat Nouri, Saber Nazari, The Role of Mediator Vision in the Relationship between Leadership Style and Organizational Learning. International Journal of Advanced Studies in Humanities and Social Science, 2019, 8(2), 158-167. http://www.ijashssjournal.com/article 84354.html 